\title{
The challenge for Australia: reconciling the Treaty
}

\author{
Sue Stanton
}

Preface $^{1}$

It is my first duty today to acknowledge the Nyungar people on whose land we gather today. I acknowledge, and wish to express my deep appreciation to all the Aboriginal communities of this region, and also all the people from the various communities represented here today - local, national and international. I pay homage to their Ancestors and to all their living Elders and associated kin. I also extend greetings and good wishes to all non-Aboriginal and non-Indigenous people present here today and to all those who support the ideals of fairness and justice, for all.

My second duty today is to acknowledge all my Ancestors, my Kungarakan Mothers, my kin - all my Kungarakan and Gurindji families of the Northern Territory.

Throughout my talk today I may use terms such as 'black' and 'white' and I would like to insist here that neither is used in derogatory or insulting manner.

Even though I may refer to Torres Strait Islanders and will use the term 'Indigenous Australians' and or Indigenous Peoples of Australia, essentially this paper is in reference to Aboriginal people of mainland Australia. The terms 'European' and 'Anglo Australians' refer essentially to those descendants of white invaders and latter day settlers, including non-Indigenous European and other migrants.

I especially acknowledge Gurindji family, and notably my Grandfathers, Grandmothers who fought the first big land rights battles at Wave Hill, and also, in recognition of all my Gurindji countrymen, those who survived and those who did not, the experiment that was to become known as 'the stolen generations'.

We can now look at the Mabo decision of $1992^{2}$ as a significant milestone. Most of us saw this as an opportunity for Australia to heal itself and to perhaps be better inclined to deal with Aboriginal people in fairer and equitable manner than it had done in the past. The feeling of optimism arose directly as the Mabo judgment promised Aboriginal people the legal power to negotiate with governments and industry in order to achieve their long-held desire to attain political and economic autonomy. The decision was celebrated as more than final recognition of Indigenous Australians as Peoples, and it was seen as more than an issue of land ownership and management. It was a celebration of the attainment of some measure of human rights. 
That's what we thought at the time. Mabo provided the opportunity for Aboriginal people to assert their common law rights, meaning that Indigenous land title based on traditional laws and customs was finally recognised by Australian law - but this recognition was not to last for long. Alas we were to be seriously disappointed. Respect for Australian law suffered yet another serious blow for most honest people, both Indigenous and Anglo and other Australians.

It would be wise of Indigenous Peoples of this country to seriously consider any further arrangements and negotiations with Australian government and Australian law, and perhaps time to consider the words supposedly uttered by Native Americans when negotiating treaties with the United States government - no frivolity intended, but those words are 'White man speak with forked tongue!'

We only have to know a little of Australia's colonial history, and to simply observe what is happening and being said in the present, to know that Aboriginal people were, and still are, placed out of sight and out of mind. The racial policies of segregation, the removal of citizenship rights, which should have been automatically granted under common law, the theft of ancient and vast estates, were all solutions, not only for the new nation at Federation, but to suit the present political agenda too. While the past Australian nation visited its own brand of evil on Aboriginal people and, ultimately on itself by laying its very foundations on the twin evils of invasion and genocide, mostly those founding principles continue to this day. Mary Kalantzis said:

... The truths of invasion and the destruction of Indigenous nations during the Colonial period were the silent and most illegal modus operandi of the so-called settlers. This ineffectual framework of rights was abandoned in the era of Federation. A new way of not having to speak about Aborigines, called without irony 'Aboriginal protection', emerged around the time of Federation and was to last half way into the twentieth century. This evolved into a system so authoritarian as to amount in many cases almost to incarceration. Aborigines were put into the same category as prisoners and lunatics in a society which was, at the time, busily setting up modern institutions to remove every manner of social evil and such evils out of sight and therefore out of mind. ${ }^{3}$

Indigenous Peoples of Australia need to seriously examine some of these past actions and the words of colonising Founding Fathers and other settlers and make comparison between the rhetoric and ask if the intent of the twin evils is still on the agenda - be careful what you ask for, you just might get it!

Xavier Herbert's memorable statement to his fellow Australian countrymen expressed exactly what the real situation for white and non-Indigenous Australia is, even at this point in the history of the nation. Nothing will change, nothing will mean anything until this restitution is made:

Until we give back to the black man just a bit of the land that was his and give it back without proviso, without strings. To give it back, 
without anything but complete generosity of spirit in concession for the evil we have done him - until we do that, we shall remain what we have always been ... a people without integrity, not a nation, but a community of thieves. ${ }^{4}$

Before presenting the challenges for Australia, a few words on the term 'Australia' - a word derived from the Latin 'Terra Australis' - carries in its roots a relationship to early modern European exploration and colonialism. Australia means 'the southern land', south from Europe, and the consequence of 'discovery' and 'settlement' that followed imposed a new word:

$\{\mathrm{It}\}$ was another Latin concept 'terra nullius'. Terra Australia was a land to be taken and colonised, as there was no pre-existing human habitation of sufficient significance even to warrant the use of the concept 'conquest'. From the point of view of European civilisation, Terra Australia was an empty land.

But we all know this was not the truth - well at least we should all know by now that the myth of terra nullius has been exposed.

There were people here already, a civilisation so subtle, variegated and complex that it is almost beyond comprehension from within a modern frame of reference - its systems of land tenure, forms of farming, kinship structures, cosmologies and languages. As the myth of 'terra nullius' has collapsed, so have the heroic claims to discovery and settlement. And the myth of English origins is contested by the fact that this is not simply an English settler society. ${ }^{6}$

One of the first challenges for Australia is for it to recognise that all the above terms have dispossessed mainland Aboriginal people of their separate identities, and that the current movement named multiculturalism, supposedly initiated and buoyed in the spirit of reconciliation, continues this dispossession as it sets out to strip, indeed rob Indigenous peoples of Australia of their unique cultural identities. Its definition also negates any reason for talk of treaties or other binding agreements, or collaborative dialogue and mutual arrangements.

The challenge of multiculturalism, if Australia is serious about it, is that it should not dictate the agenda. Especially it should not expect different ethnic and cultural groups to wear the mantle of multiculturalism while Anglo Australia remains outside the all-encompassing ethnic umbrella. This umbrella, constructed by the descendants of British invaders and non-Indigenous others, is built on specific criteria dictated by dominant western society and its culture of superiority which in turn is heavily influenced by strict racial codes. Multiculturalism in Australia is not a new or recent phenomenon but has been in operation in its present colonising form even before the introduction of the White Australia policy's official Immigration Restriction Act 1901 slowed that agenda down for a while. However, that agenda continued for Aboriginal people through the policies of 'protection' and 'assimilation' and continues today in the rhetoric of many non-Indigenous Australians, including government ministers and others in high office who insist on a brand of equality that would see Indigenous peoples of Australia being 'just like us'. The challenge for Australia is to make that 'just like us' equality a reality.

\footnotetext{
4 Herbert, 1978, as quoted in Aboriginal and Torres Strait Islander Social Justice Commissioner $\quad{ }^{5}$ Kalantzis 1998: 5. 1997: 20 (citing Australia, House of Representatives 1983, Debates, vol 134: 3489). $\quad{ }^{6}$ Kalantzis 1998: 5.
} 
How will the idea of the Treaty stand up in this multicultural agenda?

Already the idea of recognition as the Indigenous Peoples of Australia is grossly insulted by the portfolio of Aboriginal and Torres Strait Islander Affairs being lumped in with Immigration and Multicultural Affairs. Before further talkfests and numerous other workshops are held, time should be set aside to consider the implications of Aboriginal people being labelled as simply another ethnic or minority group to be dealt with under Australian government classification of 'other'. Instead Australia should meet the challenge and give true and rightful recognition and fully recognise the difference between long-term and ancient rites and customs of this land's original inhabitants as opposed to those of new and recent arrivals, including Anglo invader/settler roots. Maybe the biggest challenge yet, even before the serious talk of the Treaty or treaties, is for the appointment of an Indigenous Minister of Aboriginal and Torres Strait Islander Affairs. As well, Aboriginal and Torres Strait Islander Peoples deserve more than a government-appointed Aboriginal and Torres Strait Islander Social Justice Commissioner to monitor and represent them.

\section{The challenge for Australia post 1967 Referendum, post-Mabo and Wik and in a true spirit of reconciliation ${ }^{7}$}

The lead-up to the 1967 Referendum saw the modern political movement of Aboriginal people and organisations through the establishment of lobby groups especially. However, since that referendum there has been a growing awareness of the state of Indigenous affairs in Australia, and especially noticeable has been the inappropriate policies of the past, and also of the present. Government policies have always been enacted on behalf of Aboriginal people, usually without their input and in most cases without consultation with members of the broader Aboriginal community Australia-wide. Self-determination, an issue which rose to prominence during the late 1960s, actively pursued through the following decades and still being spoken about in the new millennium, is still to be realised. The present political and social situation is not good for Indigenous peoples of Australia and the Government, while the rhetoric in regard to reconciliation between black and white Australia remains just that.

The movement away from the demands of self-determination and towards reconciliation are proving as fruitless as previous attempts, and Aboriginal people are becoming more frustrated as their demand for basic rights continues to fall on deaf ears. What difference will a treaty or treaties make?

Recommendation number 339 of the Report of the Royal Commission into Aboriginal Deaths in Custody stated:

That all political leaders and their parties recognise that reconciliation between the Aboriginal and non-Aboriginal communities in Australia must be achieved if community division, discord and injustice to Aboriginal people are to be avoided. To this end the Committee recommended that all political leaders employ their best endeavours

\footnotetext{
7 Brought by the people of Cape York in North Queensland: the Wik Peoples v Queensland (1996) 134 ALR 637; and The Wik Peoples v State of Queensland \& Ors and The Thayorre People v The State of Queensland \& Ors (1996) 187 CLR 1. Both matters were heard in the Australian High Court on 23 December. Known as the Wik decision, this holds that native title can co-exist on pastoral leases, but the rights of pastoral leaseholders prevail over any inconsistent rights that the titleholders might have.
} 
to ensure bipartisan support for the process of reconciliation and that the urgency and necessity of the process be acknowledged. ${ }^{8}$

At the same time the Report also noted:

The racism under which Aboriginal people labour is institutionalised and systematic, and resides not just in individuals or in individual institutions but in relationships between the various institutions ... An institution, having significant dealings with Aboriginal people, which has rules, practices, habits which systematically discriminate against or in some way disadvantage Aboriginal people, is clearly engaging in institutional discrimination or racism. ${ }^{9}$

The Royal Commission recognised and acknowledged the continuing effects of past injustice. It noted that at no time had there ever been formal reconciliation between Indigenous and non-Indigenous Australia, and that the desire of Parliament was that reconciliation be achieved by the centenary of Federation in 2001 (it seems more time and effort went into celebrations of white Australia's federation party than the reconciliation agenda).

The challenge for Australia is to recognise that it was unrealistic for reconciliation to have been achieved within the space of ten short years. This is especially true for the Anglo-Australian population, which own the agenda and is burdened with 200-odd years of colonial histories that tell of injustice towards the Indigenous Peoples. They are the same people responsible for the latter-day racist agendas and policies, and are primarily responsible for the current racial intolerance and continued denial of rights. The challenge for Australia is to follow a process of healing, forgiving and understanding, dealing with legacies of gross disadvantage and injustice, and learning to recognise and value Indigenous heritage as part of national identity. It may take some time to achieve.

Even though the reconciliation agenda may have blurred lines, even though 'Aboriginal Reconciliation' has somehow become an agenda for multiculturalism, it is a good thing in many ways. For Indigenous peoples especially recognise that migrants who came to this country, commencing with the first boatload of 'illegal immigrants' in 1788, suffered levels of discrimination and prejudice not too dissimilar to Indigenous peoples. But they also recognise that many issues remain as 'unfinished business' between black and white Australia. And while the reconciliation convention recognised and 'affirmed the special place of Indigenous people in Australian society' and acknowledged that Indigenous people were 'the original owners' of the land, and Government policy was originally designed to address 'Aboriginal Reconciliation' in its broad framework, it has, like all similar policies of the past ('protection', 'assimilation', 'removal') also failed to deliver.

\section{Continuing trends and talk of a treaty - a historical revision}

As observed some 169 years ago by Governor Arthur in Tasmania:

It was a fatal error in the first settlement of Van Diemen's Land, that a treaty was not entered into with the natives ... had they received some compensation on the territory they surrendered, no matter how trifling, and had adequate laws been from the very first introduced

\footnotetext{
${ }^{8}$ Royal Commission 1991: $146 . \quad 9$ Royal Commission 1991: 146.
} 
and enforced for their protection, His Majesty's Government would have acquired a valuable possession without the injurious consequences which have followed our occupation and which must forever remain a stain upon the colonisation of Van Diemen's Land. ${ }^{10}$

While brief mentions of treaty negotiation were made in the earlier colonial days, no formal discussions were ever held. Governor Arthur of Tasmania did urge the English House of Commons in the 1840s to consider making treaties with Aboriginal people, but went no further than that. John Batman negotiated the only treaty made with Aboriginal people with the Kulin at Melbourne in 1835, but it was ruled invalid by the Governor of Victoria. His office ruled that treaties carried out by private citizens were not recognised by the Crown.

Treaties were not mentioned again for at least another one hundred years when in 1975 the Senate passed a resolution by Senator Neville Bonner ${ }^{11}$ which urged the Australian Government to at least acknowledge prior ownership of the Australian land mass by Aboriginal People. Also at that time Bonner called for the introduction of legislation to compensate Aboriginal people for the dispossession of their lands. From this historical overview it is obvious that the talk of treaties, reconciliation and compensation for land loss is not new, though it is treated as such. Australia has, over time, been presented with the challenge to right the wrongs of the past and allow itself to move to a new negotiating level, but it refuses to. Even 1967, which told of a growing awareness among the wider community that Aboriginal issues were far from resolved and that some form of settlement was urgently required if black and white Australia were to reach an accord of any description, was not heeded.

The challenge for Australia is not just for closure on many of the Indigenous issues and demands, but to give to its non-Indigenous population the right to make closure as a collective population. The challenge for Australia is for it to recognise this is not just about black Australia, but this is about the disestablishment of the current status quo as this situation has a profound impact on the daily lives, and the future lives of its non-Indigenous citizenry too. However, the Government continues to bury its head in the sand - ignoring calls for uniform national land rights legislation and changes to other inconsistent legislation which continue to confuse and disempower - as it finds the task too difficult due to powerful lobby groups such as representatives of miners and pastoralists who pressure Government into abandoning all talk of a treaty or treaties with Aboriginal people.

The Aboriginal Treaty Committee was formed in 1979 in an effort to educate and perhaps persuade non-Indigenous Australians to accept the general idea of a treaty. However The Senate Standing Committee on Constitutional and Legal Affairs in its 1983 document Two Hundred Years Later rejected suggestions of a treaty, adopting the old argument that Indigenous nations of Australia, not being sovereign entities, could not enter into treaty negotiations with the Commonwealth. How convenient is this argument? Still this Committee called for a 'compact' which possibly could eventually be inserted into the Australian Constitution by way of referendum. The challenge for Australia is to revive this discussion in 2002 and to hold this referendum.

\footnotetext{
${ }^{10}$ Arthur to Hay, 24 September 1832, CO280/35, PROL, $\quad{ }^{11}$ Neville Bonner AO (1922-1999) the first Aboriginal cited in Ryan 1981:174; see also Harris 1994: 105-6. person to be elected to Federal Parliament.
} 
The current Prime Minister resists any ideas in relation to treaty. He would never consider anything remotely similar to Hawke's suggestion of a 'Makarrata', as it seems he is quite oblivious to the history of dispossession and the racist and unjust policies of past Australian governments. So far he has only offered this patronising rhetoric:

I hope we have some kind of written understanding. I don't like the idea of a treaty because it implies that we are two nations. We are not, we are one nation. We are all Australians before anything else, one indivisible nation ... within the notion of one undivided united Australian community where our first and foremost allegiance is to Australia and nothing else. ${ }^{12}$

Well hello! The challenge for John Howard and his Australia, is to recognise just that. We are all living on the one land mass but in very unequal positions.

Many Indigenous people share strong views in relation to the 'non-reconciliation' movement, and its lack of commitment to the overall treaty dialogue. Many fail to get excited about the entire concept. Noel Pearson, Executive Director, Cape York Land Council, is one of many who holds the view that Aboriginal people don't need to be reconciled to anything. Many Aboriginal leaders and others condemn the notion of reconciliation and have questioned the motives of such a movement as they are uncertain of its direction and wary of its possible hidden agendas.

The challenge for Australia is to prove that this is not the case.

Many ambiguities continue to surround the concept of reconciliation and a great number of Aboriginal people are cautious about the capacity of the reconciliation policy to put in place the effective and long-lasting changes that are required. After all, Aboriginal people have had extensive experience with government policies in the past and have every right to remain sceptical.

Indigenous critics have also noted that in addition to the ambiguity and vague nature of the reconciliation rhetoric, major issues important to them such as sovereignty, treaty, and land rights, are all conspicuously absent from the overall government agenda. The approach to dealing with Indigenous issues also does not provide any suitable mechanism through which the voices of all Indigenous Australians may be heard. The late Kevin Gilbert, who was Chairperson of the Treaty ' 88 campaign and who fought for the establishment of a treaty which would enshrine the rights of Aboriginal people as well as advance dialogue on issues of Aboriginal sovereignty, eventually became highly critical of the entire process, and refused flatly to accept either the idea of a Council for Aboriginal Reconciliation or the idea of reconciliation at all. Gilbert however strongly supported the notion of a treaty. ${ }^{13}$ He stated:

We have to look at the word 'reconciliation'. What are we to reconcile ourselves to? To a holocaust, to massacre, to the removal of us from our land, from the taking of our land? The reconciliation process can achieve nothing because it does not at the end of the

\footnotetext{
${ }^{12}$ John Howard 1998. $\quad{ }^{13}$ In 1988 Gilbert, who was awarded the Human Rights and Equal Opportunity Commission's Human Rights Award for Literature, returned the award stating that he could not accept such an award while Aboriginal people were still being denied human rights in their own land.
} 
day promise justice. It does not promise a Treaty and it does not promise reparation for the taking away of our lives, our lands and our economic and political base. Unless it can return to us these very vital things, unless it can return to us an economic, a political and a viable base, what have we? A handshake? A symbolic dance? An exchange of leaves and feathers or something like that? ${ }^{14}$

The challenge for Australia in relation to both the Treaty and the reconciliation agenda is to recognise the fear and uncertainty felt by Aboriginal people, to alter its own direction, to recognise that government appointments and not representatives elected by Aboriginal peoples themselves cause much of the distrust and reluctance among Aboriginal people to be involved. Then it must radically change that approach.

Members of the Aboriginal Provisional Government (APG) were highly critical of the processes involved in initial reconciliation agendas, and perhaps are still suspicious of the current Treaty dialogue. Like many other Aboriginal individuals, they know only too well that, usually, those appointed to represent the entire Aboriginal population are not only well chosen, but must be politically middle of the road so as to cause the least amount of stirring and resistance. The challenge for Aboriginal people is not to fall into this trap - the old divide and rule trick.

Michael Mansell of the APG observed that there is an 'uncanny similarity between rhetoric surrounding the policy of reconciliation and that attached to the policies of one-time politician Pauline Hanson and her former One Nation Party party. Like the Prime Minister now, Pauline Hanson spoke of a 'united Australia', 'we are one'. Yet, in very contradictory terms, the Prime Minister also speaks of the 'special position' and 'prior ownership', but he does not wish to make 'special considerations', or to give anything back, or to consider a treaty or treaties.

In conclusion I quote from the words of Glenn T Morris of the Colorado chapter of the American Indian Movement (AIM), who stated in 1992:

If people are genuinely interested in honouring Indians, try getting your government to live up to the more than 400 treaties it signed with our nations. Try respecting our religious freedom which has been repeatedly denied in federal courts. Try stopping the ongoing theft of Indian water and other natural resources. Try reversing your colonial process that relegates us to the most impoverished, polluted, and desperate conditions in this country ... Try understanding that the mascot issue is only the tip of a very huge problem of continuing racism against American Indians. Then maybe your ['honors'] will mean something. Until then, it's just so much superficial, hypocritical puffery. People should remember that an honor isn't born when it parts the honorer's lips, it is born when it is accepted in the honoree's ear. ${ }^{15}$

Sounds all too familiar when put in the Aboriginal context. Be careful what you ask for a treaty is a treaty after all. ${ }^{14}$ Gilbert as quoted in Mudrooroo 1995: 228-9. $\quad{ }^{15}$ As quoted in Churchill 1992: 219. Ward Churchill (Keetoowah Cherokee), member
of AIM since 1972, Professor of Ethnic Studies at University of Colorado, Boulder. 


\section{Postscript}

I write in memory of Gatjil Djerrkura, respected Elder and spokesperson for Wungurri people and many other Aboriginal people in this country. We must heed some of his final words about the paternalistic model of government. These are the usual rhetorical responses, it seems, to every Indigenous issue. Gatjil referred to the dismantling of ATSIC:

It is no coincidence that $\mathrm{Mr}$ Howard announced his attention to abolish ATSIC ... the manner in which it was made and the language in which it was delivered. In the classic imperial fashion, without negotiation, without understanding and with little empathy, the great white leader announced that Aboriginal people had, yet again, been a 'failure' ... The Prime Minister walks early and often, but he has never walked for reconciliation. ${ }^{16}$ 


\section{References}

Aboriginal and Torres Strait Islander Social Justice Commissioner 1997, Fifth Report 1997: Report to the Federal Attorney-General as per section 46C.(1) of the Human Rights and Equal Opportunity Commission Act 1986, available at http://www. hreoc.gov.au/pdf/social_justice/sj_report 97.pdf

Churchill, Ward 2002, Acts of Rebellion: The Ward Churchill reader, Routledge, New York.

Djerrkura, Gatjil 2004, Our paternalistic model of government, speech at the launch of Mark McKenna's This Country: A Reconciled Republic?, reproduced in full in The Canberra Times, 14 May.

Harris, JW 1994, One blood, Albatross, Sydney.

Howard, John 1998, on 60 Minutes (Beazley and Howard election debate), 13 September, available at http://www.australiapolitics.com/ elections/1998/debate/html

Kalantzis, Mary 1998, Reconsidering the Meaning of Our Commonwealth, Women's Constitutional Convention, Canberra, January 29-30.

- 2001, 'Recognising Diversity', The Barton Lecture \# 3, ABC Radio National, 25 February.

Mudrooroo 1995, Us mob, Angus and Robertson, Melbourne.

Royal Commission into Aboriginal Deaths in Custody 1991, National Report, vol 5, AGPS, Canberra.

Ryan, L 1981, The Aboriginal Tasmanians, Allen and Unwin, St Leonards.

Senate Standing Committee on Constitutional and Legal Affairs 1983, Two Hundred Years Later - A Report on the Feasibility of a Compact or 'Makaratta' between the Commonwealth and Aboriginal People, AGPS, Canberra.

\section{Legislation}

Immigration Restriction Act 1901 (Cth).

\section{Case law}

Mabo and Ors $v$ The State of Queensland (No 2) (1992) 175 CLR 1.

Wik Peoples v Queensland (1996) 134 ALR 637.

The Wik Peoples $v$ The State of Queensland \& Ors; The Thayorre People $v$ The State of Queensland \& Ors (1996) 187 CLR 1. 